NBER WORKING PAPER SERIES

\title{
MANAGING BANK LIQUIDITY RISK: HOW DEPOSIT- LOAN SYNERGIES VARY WITH MARKET CONDITIONS
}

\author{
Evan Gatev \\ Til Schuermann \\ Philip E. Strahan \\ Working Paper 12234 \\ http://www.nber.org/papers/w12234
NATIONAL BUREAU OF ECONOMIC RESEARCH
1050 Massachusetts Avenue
Cambridge, MA 02138
May 2006

\begin{abstract}
We would like to thank the FDIC Center for Financial Research for financial support, as well as for helpful comments on the research. We would also like to thank seminar participants at Boston College, Ohio University, Tilburg University, and the University of Amsterdam. Kristin Wilson assisted with preparation of the data. Any views expressed represent those of the authors only and not necessarily those of the Federal Reserve Bank of New York or the Federal Reserve System. Corresponding author: Strahan is at Boston College, 140 Commonwealth Avenue, Chestnut Hill MA, 02467, Philip.strahan@bc.edu, 617-552-6430. The views expressed herein are those of the author(s) and do not necessarily reflect the views of the National Bureau of Economic Research.
\end{abstract}

(C)2006 by Evan Gatev, Til Schuermann and Philip E. Strahan. All rights reserved. Short sections of text, not to exceed two paragraphs, may be quoted without explicit permission provided that full credit, including () notice, is given to the source. 
Managing Bank Liquidity Risk: How Deposit-Loan Synergies Vary with Market Conditions Evan Gatev, Til Schuermann and Philip E. Strahan

NBER Working Paper No. 12234

May 2006

JEL No. G18, G21

\begin{abstract}
$\underline{\text { ABSTRACT }}$
Liquidity risk in banking has been attributed to transactions deposits and their potential to spark runs or panics. We show instead that transactions deposits help banks hedge liquidity risk from unused loan commitments. Bank stock-return volatility increases with unused commitments, but the increase is smaller for banks with high levels of transactions deposits. This deposit-lending risk management synergy becomes more powerful during periods of tight liquidity, when nervous investors move funds into their banks. Our results reverse the standard notion of liquidity risk at banks, where runs from depositors had been seen as the cause of trouble.
\end{abstract}

Til Schuermann

Banking Studies Function

Federal Reserve Bank of New York

33 Liberty Street

New York, NY 10045

schuermann@ny.frb.org

Philip E. Strahan

Carroll School of Management

324B Fulton Hall

Boston College

Chestnut Hill, MA 02467

and NBER

strahan@bc.edu 


\section{Introduction}

Banks have traditionally provided liquidity on demand, both to borrowers with open lines of credit and un-drawn loan commitments (we use these terms interchangeably), and to depositors in the form of checking and other transactions accounts. Both contracts allow customers to receive cash on short notice. In fact, the combination of these two products in a single firm constitutes a reasonable working definition of a 'bank'. The liquidity insurance role of banks, however, exposes them to the risk that they will have insufficient cash to meet random demands from their depositors and borrowers. In this paper, we show that combining these two products actually reduces risk and can thus help explain the traditional structure of banks. ${ }^{1}$

There is a large theoretical literature that attempts to understand banks' role in liquidity production. This literature initially emphasized the risks associated with demand deposits that expose banks to the possibility of a catastrophic run. Diamond and Dybvig (1983) explain the structure of banks by arguing that by pooling their funds in an intermediary, agents can insure against idiosyncratic liquidity shocks while still investing most of their wealth in high-return but illiquid projects. This structure, however, leads to the potential for a self-fulfilling bank run and sets up a policy rationale for deposit insurance. More recent theoretical and empirical studies have focused on liquidity risk

\footnotetext{
1 Previous research identifies several other reasons why banks combine deposits and loans. For example, Fama (1985) suggests that information stemming from the business checking account could give banks an advantage in lending over other financial intermediaries; for recent empirical evidence, see Mester, Nakamura, and Renault (2002). Berlin and Mester (1999) argue that banks' access to inelastically supplied funds (core deposits) allows them to offer borrowers insurance against credit shocks. Other studies suggest that because bank loans are illiquid, and thus make "bad" collateral against which to borrow, the optimal capital structure is one characterized by very liquid (or short-term) liabilities that subject the bank to the possibility of a run (e.g., Calomiris and Kahn (1991), Flannery (1994), and Diamond and Rajan (2001)). For a summary of empirical evidence, see Strahan (2005).
} 
coming from the asset side of the bank's balance sheet. ${ }^{2}$ Banks that make commitments to lend are exposed to the risk of unexpected liquidity demands from their borrowers.

This paper presents a systematic empirical analysis of liquidity risk stemming from both sides of bank balance sheets. We study how deposit taking and commitment lending interact. We find that asset-side and liability-side liquidity risks are offsetting rather than reinforcing, meaning that combining deposits and commitment lending provide a liquidity-risk hedge for banks.

Our point of departure is the model presented by Kashyap, Rajan and Stein (2002), hereafter KRS, who explain why banks tend to combine transactions deposits with loan commitments based on a risk-management motivation: as long as the demand for liquidity from depositors through the checking account is not highly correlated with liquidity demands from borrowers, an intermediary will be able to reduce its need to hold cash by serving both customers. Thus, their model yields a diversification synergy between demand deposits (or transactions deposits more generally) and loan commitments. As evidence, KRS report a robust correlation across banks between unused loan commitments and transactions deposits. The correlation is robust to variations in the definition of loan commitments, to bank size, and is also consistent across time. However, KRS do not test the key idea in their model - the idea that by exposing themselves to asset-side and liability-side liquidity risks simultaneously, banks can actually enjoy a diversification, or risk reducing, synergy.

In this paper, we test the basic premise of the KRS model - that liquidity risks

\footnotetext{
${ }^{2}$ For example, Berger and Bouwman (2005) document the importance of banks in liquidity production and show that this role has grown sharply over time. There is also a growing literature showing the liquidityrisk management or liquidity shocks to banks affect loan supply. See Paravisini (2004), Kwaja and Mian (2005), Loutskina (2005) and Loutskina and Strahan (2006).
} 
stemming from the two fundamental businesses of banking yield a diversification benefit. The results suggest that bank risk, measured by stock return volatility, increases with unused loan commitments, reflecting asset-side liquidity risk exposure. This increase, however, is mitigated by transactions deposits. In fact, risk does not increase with loan commitments for banks with transactions deposits in the top third of the distribution.

Table 1 illustrates our key finding in a simple and intuitive way. The table reports our measure of risk (average stock-return volatility, equal to the annualized return standard deviation) for large, publicly traded banks, along with several bank characteristics, including a liquidity ratio (cash + securities to assets), total assets, Fed Funds purchased to assets, and the ratio of equity to assets. ${ }^{3}$ We divide the data into nine cells, based on the level of loan commitments (unused commitments divided by unused commitments plus loans) and the level of transactions deposits (relative to total deposits). Each cell reports the simple average for all observations in that part of the distribution. Looking across rows, stock-return volatility (our measure of risk) clearly increases with loan commitments for banks with low and moderate levels of transactions deposits (columns 1 and 2). But, risk does not increase for banks with high levels of transactions deposits (column 3). In other words, loan commitments do not seem to expose banks with high levels of transactions deposits to much risk.

Table 1 also shows that banks with high levels of unused commitments tend to be larger than average. Moreover, banks that operate without the benefit of high levels of transactions deposits hold more cash than other banks (last row of column 1). Thus, the high balance sheet liquidity held by these banks does not fully offset the risk from liquidity exposure associated with high levels of unused commitments. Banks with

\footnotetext{
${ }^{3}$ We describe our sample and data in detail below.
} 
unused commitments thus can conserve on holding cash by funding themselves with transactions deposits. ${ }^{4}$

In the empirical analysis below, we show that this result holds up in a regression context, even after controlling for bank size (which is correlated with unused commitments), as well as measures of market and credit risk exposure. The result is robust to alternative measures of stock-return volatility, to statistical modeling approaches, as well as to variations in the set of control variables included in the model.

We then extend the benchmark results by testing how the deposit-lending diversification synergy varies with market conditions. The hedging benefits of combining loan commitments and transactions deposits are strongest when market-wide liquidity supply is low, which we proxy with the Commercial Paper-Treasury Bill spread (wide spreads indicate low liquidity). For banks with the highest levels of transactions deposits, risk actually decreases with the level of unused commitments when spreads are high. The deposit-lending hedge is most powerful when the short-term credit markets become expensive because banks face increased take-down demands from borrowers constrained by tight market conditions at the same time that they experience funding inflows into their transactions deposits (Gatev and Strahan, 2006). These inflows and outflows of liquidity offset, thus strengthening the risk-management synergy. Our results thus show that transactions deposits play a critically important role in allowing banks to manage their liquidity risk, especially during periods of market pullbacks. The findings

\footnotetext{
${ }^{4}$ We do not explicitly model the tradeoffs associated with banks' varying their levels of balance sheet liquidity (cash and securities) to manage risks from unused commitments or deposits. Banks choose these levels jointly, along with other capital structure policies such as leverage and debt maturity. A full analysis of the substitutability across these financial policies would require a set of identifying instruments. Instead, we focus on the co-variation between these endogenous financial variables and our outcome measure, the bank's stock-return volatility.
} 
strengthen the KRS theoretical argument, and they help explain the robust positive correlation across banks between transaction deposits and loan commitments, both over time and across a wide range of economies.

The rest of the paper proceeds as follows. In the next section provide a brief summary of some previous research. In Section III, we explain the sample design and our empirical strategy, and the results are presented in Section IV. Section V provides some concluding remarks.

\section{Background and previous research}

The growth of the commercial paper market and subsequently of the junk bond market in the 1980s and 1990s suggests that the role of banks in the financing of large businesses has been diminished (Mishkin and Strahan, 1998). However, this noted evolution away from banks and toward the securities markets has not rendered banks irrelevant (see Boyd and Gertler, 1994). While banks do provide less funding than before, they remain important to large firms as providers of backup liquidity support to the commercial paper market financing. Banks act as the "liquidity provider of last resort” by promising to offer cash on demand through commercial paper backup lines of credit. $^{5}$ Banks also continue to provide liquidity to customers through their role as issuers of transactions deposits.

Why do banks provide liquidity to both sets of customers? To the extent that liquidity demands are independent across both businesses and depositors, a bank can use scale-related diversification to mitigate its need to hold cash to meet unexpected liquidity

\footnotetext{
${ }^{5}$ Banks also continue to bear significant credit risk through off-balance sheet guarantees such as standby letters of credit.
} 
demands from its depositors and borrowers. ${ }^{6}$ Kashyap, Rajan and Stein (2002) present a model based on this notion, in which a risk-management motive explains the combination of transactions deposits and loan commitments. They argue that as long as the demand for liquidity from depositors through the checking account is not highly correlated with liquidity demands from borrowers, an intermediary will be able to reduce its need to hold cash by serving both customers. Thus, their model yields a diversification synergy between transactions deposits and unused loan commitments.

This synergy helps explain the basic structure of banks. As evidence, KRS show that banks offering more transaction deposits tend also to make more loan commitments. In Gatev and Strahan (2006), we suggest a stronger hypothesis, supported by our findings that the correlation is not only low but is in fact negative. Transactions deposits can be viewed as a natural hedge because flows into these accounts offset the systematic liquidity risk exposure stemming from issuing loan commitments and lines of credit.

Our previous work extends KRS by considering the possibility that liquidity production could expose banks to systematic liquidity risk. A bank with many open credit lines, for example, may face a problem if, rather than facing just idiosyncratic demands for cash, it sometimes faces increased demand for liquidity by many borrowers simultaneously. For example, during the first week of October 1998, following the coordinated restructuring of the hedge fund Long Term Capital Management (LTCM), spreads between safe Treasury securities and risky commercial paper rose dramatically. Many large firms were consequently unable to roll over their commercial paper as it came due, leading to a sharp reduction in the amount of commercial paper outstanding

\footnotetext{
${ }^{6}$ In a world with taxes, financial distress, or agency costs, holding cash or other liquid assets is costly for banks and other firms (e.g. Myers and Rajan, 1998).
} 
and a corresponding increase in take-downs on pre-existing lines of credit (Saidenberg and Strahan, 1999). As a result of this market pullback, banks faced a systematic spike in demand for cash as many of their largest customers drew funds from pre-existing backup lines of credit. Gatev and Strahan (2006) show, however, that funding supply to banks increases as the availability of market liquidity declines. Thus, banks were able to weather the 1998 storm because deposit funding flowed in just as it was needed by borrowers.

Why do banks, as opposed to other financial intermediaries, enjoy funding inflows when market liquidity dries up? First, the banking system has some explicit guarantees of its liabilities (government-backed deposit insurance up to $\$ 100,000)^{7}$

Second, banks have access to emergency liquidity support from the central bank. Third, historical precedent suggests that large banks, such as Continental Illinois in the early 1980s and Citicorp in the early 1990s, may be supported if they face financial distress (O’Hara and Shaw, 1990). Thus, funding inflows occur during market pullback in part because banks are rationally viewed as explicitly or implicitly insured by governments. Consistent with this notion, Pennacchi (2006) finds that during the years before the introduction of federal deposit insurance, bank funding supply did not increase when spreads tightened.

In a case study, Gatev, Schuermann and Strahan (2005) focus on the behavior of deposit flows across banks during the 1998 crisis, which began with the Russian government bond default in the middle of August. During the three-months leading up to

\footnotetext{
${ }^{7}$ Deposit insurance limits have recently been expanded for the first time sine 1980. In addition, some small banks have begun to avoid binding limits on deposit insurance by splitting very large deposits across multiple institutions. For a broad discussion for deposit insurance and policy ramifications, see Kroszner and Strahan (2005).
} 
the crisis, bank stock prices where buffeted by news of the Russian crisis, followed by the demise of the hedge fund LTCM in late September, and finally by the drying up of the commercial paper market in the first week of October. ${ }^{8}$ Chava and Purnanadam (2005) provide evidence that the $\mathrm{CP}$ market ceased to function at the beginning of October by comparing abnormal returns for firms with and without access to this market. They show first that stock prices of CP issuers fell much less than other firms when bank financial condition deteriorated during September of 1998 (while markets continued to function). During the first two weeks of October, however, the stock prices of all firms, regardless of their ability to access the CP market, fell equally. Thus, all firms became bank dependent - even CP issuers - during these weeks because CP markets ceased to function and even large corporations relied on banks for liquidity.

Figure 1 shows the aggregate effects of the 1998 crisis on stock-return volatility. We plot bank stock volatility and volatility of the S\&P 500, measured as the conditional volatility from an EGARCH $(1,1)$ model. The figure highlights the difference between bank risk exposures in different business conditions. During the crisis, bank stock volatility was higher than overall general market volatility, while it was lower in the “normal” pre-crisis period.

To understand how banks weathered this liquidity storm, in Gatev, Schuermann and Strahan (2005) we explore the cross-sectional patterns in deposit flows during the 1998 liquidity crisis. We found first that investors moved funds from markets into banks; second, that banks with higher levels of transactions deposits before the crisis had the largest flows of new money during the crisis; and third, that all of the flows of new

\footnotetext{
${ }^{8}$ For policy discussion on LTCM, see Edwards (1999). For a discussion of bank exposure to the hedge funds, see Kho, Dong and Stulz (2002) and Furfine (2002).
} 
money were concentrated in bank demand deposits. So, banks structured to bear increased demands for liquidity from borrowers (i.e. banks with transactions deposits) could meet those demands easily (because money flowed into those accounts). Thus, government safety nets can explain why banks generally receive funding during crises, but the evidence from Gatev et al. as well as Kashyap et al. suggests that the structure of banks matters too.

Before the introduction of government safety nets, transactions deposits could sometimes expose banks to liquidity risk when consumers together removed deposits, either to increase consumption or because they had lost confidence in the banking system. This bank-run problem has traditionally been viewed as the primary source of liquidity risk and creates a public policy rationale for FDIC insurance as well as reserve requirements for demand deposits (Diamond and Dybvig, 1983). In crisis, investors now run to banks, not away from them (at least they do in the U.S.). And, banks funded with transactions accounts receive the inflow. Thus, rather than open banks to liquidity risk, transactions deposits today help banks hedge that risk, which now stems more from the lending side. We now turn to our direct tests of this idea.

\section{Empirical Methods}

\section{Sample}

We start by identifying the 100 largest publicly traded domestic banks (based on market capitalization) at the beginning of each year from 1990 to $2002 .{ }^{9}$ We focus on large banks for several reasons. First, large-bank stocks trade frequently, so daily stock

\footnotetext{
${ }^{9}$ We begin in 1990 because that is the first year when unused retail loan commitments are available which we shall control for as a robustness check. Prior to 1990 only total commitments are reported.
} 
returns are available and reliable. For smaller banks, lack of active trading every day poses problems in estimating the conditional volatility model (see below). Second, large banks hold the vast majority of the banking system's assets. For example, about 60 percent of bank assets were held by the 100 largest banks during our sample. Third, large banks are more actively engaged in commitment lending than small banks.

After identifying the top 100, we drop all banks that engaged in a merger or acquisition (M\&A) during the year of the deal itself (but not in other years). For example, fifteen of the large banks were involved in M\&A in 1990, leaving 85 in our sample. ${ }^{10}$ Next, we construct the weekly conditional volatility for stock returns for these banks (details below). For our purpose, a week begins and ends on Wednesday, as this is the weekday with the fewest public holidays which might close the markets. We repeat this sampling procedure for every year between 1990 and 2002. Note that it is important to drop both acquirers and targets around M\&A announcements because speculation about such deals generates a large amount of stock price volatility having nothing to do with the basic risks banks face (market, credit, liquidity, etc.). So, for example, we drop both JP Morgan and Chase during the year of their merger, but these two banks are included as two separate banks in the years prior to the merger, and as a single bank in the year after the merger. As a result, the maximum number of banks in any year is 98 (2002), and the minimum is 68 (1996). The sample-generating procedure leaves us with 170 banks, and almost 50,000 bank-week observations overall.

\footnotetext{
${ }^{10}$ Traded equity reflects the profits and risk of the entire bank holding company, so our use of the term bank refers to the whole holding company. In collecting characteristics, we use data for the lead bank within the holding company.
} 


\section{Conditional Mean Volatility}

We construct our conditional stock-return volatilities by fitting daily returns to a GARCH $(1,1)$ model for each bank-year, as follows. Let $r_{i, t+1}$ be the return for bank $i$ from $t$ to $t+1$. Then bank returns may be characterized by

$$
\begin{aligned}
& r_{i, t+1}=\mu_{i, t+1}+\varepsilon_{i, t+1} \\
& \sigma_{i, t+1}^{2}=\omega+\alpha \varepsilon_{i, t}^{2}+\beta \sigma_{i, t}^{2}, \quad \omega, \alpha, \beta>0,
\end{aligned}
$$

where $\mu_{i, t+1}$ is a non-zero, possibly time-varying drift. For estimation, the innovation $\varepsilon_{i, t+1}$ is assumed to be conditionally normally distributed with time-varying GARCH(1,1) volatility as specified in the second equation of (1).

Based on the coefficients estimated in the GARCH model, we construct daily conditional volatility, and then we aggregate up the daily volatilities to weekly frequency. ${ }^{11}$ Table 1 reports the simple average level of these conditional volatilities, normalized to represent the annualized standard deviation of the stock return. We split the data into nine cells, based on the joint distribution of the level of the ratio of transactions deposits to total deposits and the level of unused loan commitments to total commitments plus total loans (our measure of asset-side liquidity exposure). This admittedly simple table illustrates the main hedging idea of our research: banks with high levels of transactions deposits have similar levels of risk regardless of their loan-liquidity exposure (column 3). In contrast, risk increases with loan liquidity risk (unused loan commitments) for banks at the low end of the transactions deposits distributions (column 1). Increasing unused loan commitments comes with an increase in risk of nearly 30

\footnotetext{
${ }^{11}$ To aggregate volatilities from daily to lower frequencies, say weekly, we take the average over that week and scale by $\sqrt{5}$, allowing for the possibility of missing days due to, for instance, holidays.
} 
percent for these banks (from 0.28 to 0.36 ). The same patterns show up in the medians within each cell (not reported). The deposit base therefore seems to act as a natural hedge against liquidity exposure from loan commitments. ${ }^{12}$

\section{Regression Specification}

To demonstrate these results more systematically, we estimate an empirical model of the conditional volatility as a function of bank liquidity exposure, deposits, and other market-level and bank-level characteristics, as follows:

$$
\begin{aligned}
\log \left(\sigma_{i t}\right)= & \beta_{0}+\beta_{1} \text { LoanCommitments }_{i, t-1}+\beta_{2} \text { DepositBase }_{i, t-1}+ \\
& +\beta_{3}\left(\text { LoanCommitments }_{i, t-1} * \text { DepositBase } e_{i, t-1}\right)+ \\
& + \text { Bank-Level and Market-Level Control Variables }+u_{i, t},
\end{aligned}
$$

where $\sigma_{i t}$ is the conditional stock-return volatility for bank $i$ at time $t$ from the first-stage GARCH (1,1) model in equation (1); LoanCommitments $s_{i, t-1}$ is the ratio of unused loan commitments to commitments plus loans (measured in the previous quarter); and, DepositBase $_{i, t-1}$ is the ratio of transactions deposits to total deposits (again, from the prior quarter). If deposits help banks hedge asset-side liquidity risk, as suggested by Table 1 , then $\beta_{3}<0 .{ }^{13}$

\footnotetext{
${ }^{12}$ Notice that the hedge seems to go both ways. That is, for banks with low levels of loan commitments (first row), higher transactions deposits come with higher risk (from 0.28 to 0.32 ). On the other hand, for banks with high levels of commitments, higher transactions deposits come with lower risk (from 0.36 to 031).

${ }^{13}$ We have also estimated regressions like (1) using the level of volatility as well as the square of volatility (variance). These results are similar in terms of statistical and economic significance to those reported here.
} 


\section{Variable Definitions and Data Sources}

As time-varying controls in the regression, we include the contemporaneous stock return volatility for the S\&P 500 as a whole, estimated with a GARCH $(1,1)$ model in the same fashion as the bank specific volatilities; the three-month T-bill rate; and the spread between the high-grade three-month commercial paper rate and the three-month T-bill rate. To be consistent with the conditional volatilities, the interest rate data are taken for the Wednesday of a given week.

For bank-level controls, we include the following: the log of assets (size control), the ratio of cash plus securities to total assets (liquid asset measure), the ratio of capital to assets (capital adequacy measure), and the ratio of Fed Funds purchased to assets (a measure of access to the Fed Funds market, a liquidity pool). Controlling for size is particularly important given its correlation with loan commitments (recall Table 1). We also consider a second loan commitment variable as a robustness test that removes retail commitments (e.g. credit card lines) from both the numerator and the denominator of LoanCommitments $_{i, t-1}$. Unused retail commitments may be less likely to expose banks to risk relative to business-loan commitments, where take-down demand is both less predictable and more likely to have a systematic component such as the one observed in the fall of 1998.

Data on unused commitments, transactions deposits, as well as the other bank characteristics, come from the most recent quarter of the Reports of Income and Condition ('call reports') prior to the time at which we measure the stock return variability. So for example, all weeks in the second quarter of 1990 are matched to call report data for first quarter of 1990. Stock return data come from the Center for 
Research in Securities Prices (CRSP), inclusive of dividend payments and adjusted to account for stock splits. Data on interest rates are available daily from the Federal Reserve Board of Governors. Note that since the regulatory data is available only at quarterly intervals, the bank characteristics remain unchanged for all weeks within a given quarter.

\section{Summary Statistics}

Table 2 reports the summary statistics for all of the variables reported in the regressions. Bank-stock volatility averages about 30 percent per year, well above the 16 percent for the S\&P 500 index. We would expect, of course, index volatility to be lower due to portfolio effects. In our sample, the mean loan commitment ratio is about 0.32 and the mean level of transactions deposits to total deposits equals about 0.26. As in KRS, banks with high levels of loan commitment also tend to focus on transactions deposits.

For instance, 46 percent of the observations in Table 1 line up on the diagonal (relative to 33 percent if the data were evenly distributed). For the control variables, we use ratios that lie between zero and one, interest rates in percent, or, in the case of assets, we have logged the variable. Hence, there is no concern about outliers driving the results.

\section{$\underline{\text { IV. Results }}$}

\section{Main Findings}

Table 3 reports the benchmark set of findings. We report the regressions from equation (2) above using all of our data. The table reports four specifications, two based on the total commitments ratio, and two that exclude retail commitments. For each of these, we report a simple model with just log of assets as a bank control, and a more 
complex model that adds the liquid assets ratio (cash + securities), the ratio of Fed Funds purchased to assets, and the capital-asset ratio. Note that we have a very large sample (almost 50,000 bank-week observations), but we cluster the data by bank to avoid assuming independence over time for each bank. This clustering raises the standard errors by a factor of about 10 relative to the OLS standard errors.

The results in Table 3 support the idea that loan commitment risk (liquidity risk) can be hedged with transactions deposits. The coefficient on the interaction term $\left(\beta_{3}\right)$ is negative and highly statistically significant, ranging from -1.6 to -1.7 across the four specifications. For a bank with transactions deposits at the $10^{\text {th }}$ percentile of its distribution (0.12), the coefficients suggest that loan commitments expose banks to risk. For such a bank, a one standard deviation increase in the loan commitment ratio would come with an increase in stock-return volatility of about 2.5 percentage points (relative to a sample standard deviation of about 13 percentage points). For a bank with transaction deposits at the $90^{\text {th }}$ percentile (0.38), however, the same increase in loan commitments comes with an increase in stock-return volatility of just 0.6 percentage points.

Figure 2 illustrates the relationship between stock-return volatility and unused loan commitments, comparing high- and low-transactions deposit banks. The figure plots the predicted volatility based on the regressions coefficients in Table 3 (column 2) for banks at the $10^{\text {th }}$ and $90^{\text {th }}$ percentiles of the transactions deposit distribution. As the figure shows clearly, risk increases with liquidity exposure from unused loan commitments for banks without high levels of transactions deposits. In contrast, risk does not vary with loan commitments for banks with high transactions deposits. 


\section{Robustness Tests}

Tables 4-6 report three robustness tests. First, we replaced the GARCH $(1,1)$ estimate of conditional stock-return volatility with realized volatility (the weekly average of squared returns). Table 5 focuses on the statistical assumptions, and Table 6 focuses on the potential for omitted variables bias. Table 4 shows that the precise modeling technique for estimating volatility has almost no impact on any of the coefficients on the bank variables. The variable that accounts for market conditions (the paper-bill spread), however, more than doubles and becomes much more statistically powerful. This makes sense because the realized volatilities will adjust immediately to changing market conditions, while the GARCH estimates will only do so gradually. The goodness of fit of the model also declines sharply, presumably because, in contrast to the GARCH estimates, again because the realized volatilities are not smoothed over time.

In columns 1 and 2 of Table 5, we report the 'between' estimator - that is, the regressions are run using bank-level time-series averages. Thus, coefficients are driven only by cross-sectional variation. We find that the hedging coefficient remains similar to the results in Table 3 in terms of magnitudes. Levels of statistical significance fall slightly because the between estimator has just 170 separate banks. We report the 'within' estimator in columns 3 and 4. The within estimator, also sometimes called the fixed effects estimator, allows each bank to have its own intercept in the regressions. Because the bank-level intercept strips out all cross-sectional variation before estimating the slope coefficients, the results are driven solely by within-bank variation over time. Again, we continue to find strong evidence of the transaction deposit-loan commitment diversification synergy. The results in Table 5 suggest that the hedging effects of 
combining loan commitments with transactions deposits are present with approximately equal magnitude in both the cross-sectional and time-series dimensions.

Next, we consider the possibility that the observed bank equity risk is driven by risks other than liquidity (Table 6). For example, credit and market risk exposures are two of the primary risks faced by banks (and, not coincidentally, these are the risks that the Basel Capital Accord focuses on). We want to rule out the possibility that our results reflect credit or market risk exposure rather than liquidity risk exposure. To test this idea, we include the ratio of commercial and industrial loans to assets and commercial real estate loans to assets as ex-ante proxies for bank credit risk exposure. In general, business loans are the part of the bank loan portfolio with the most credit risk (Demsetz and Strahan, 1997; Stiroh, 2005). ${ }^{14}$ We also include the ratio of non-performing loans to assets as a measure of ex-post risk, and, in some specifications, we also add the ratio of net charge offs to assets, and the ratio of loan loss provisions to assets. ${ }^{15}$ To control for cross-bank variation in market risk exposure, we include the ratio of trading account assets to total assets.

The results suggest that while our measures for both credit and market risk are correlated with stock return volatility in the expected ways, the effects of the liquidityrisk-offsetting influence of deposits is robust to the inclusion of these other risks (columns 1 and 2). The coefficients on C\&I loans and trading account assets enter with positive signs (significant in two of the four models). Even more striking, both nonperforming loans and loan loss provisions have substantial power to explain stock-return

\footnotetext{
${ }^{14}$ Loan losses tend to be high for credit card loans, but these losses are much more predictable than losses associated with business lending.

${ }^{15}$ Non-performing loans are defined as loans more than 30 days past due plus loans no longer accruing interest but not yet charged off the balance sheet.
} 
volatility, but the inclusion of these variables has little impact on the coefficients of interest. Most important, the coefficient on the interaction term remains negative and significant, and more generally the results are similar to those reported before.

The last two columns of Table 5 repeat these regressions, but now we replace the time-varying control variables (S\&P 500 volatility, the level of interest rates, and the spread) with a full set of time indicator variables (i.e. a separate intercept for each week). The market-level variables are not identified in this model because the time effects sweep out all common shocks to bank-stock volatility. The advantage of this approach is that time effects remove any missing common factors that may move bank-stock volatility around, such as changes in regulations, macroeconomic shocks, changes in monetary policy, and so on. ${ }^{16}$ The effects of interest, again, remain robust in these specifications. ${ }^{17}$ Varying Market Conditions

Table 7 sharpens our benchmark results, and ties the findings more closely to liquidity risk. We compare our model coefficients from 'normal' market conditions with the coefficients estimated when market liquidity becomes scarce. During normal conditions, the diversification synergy of combining transactions deposits and loan commitments comes from reducing the effects of idiosyncratic liquidity demands (as in KRS). Following our earlier work, we use the spread between commercial paper rates and T-bill rates as an indicator for the supply of market liquidity. As we show in Gatev and Strahan (2006), when market liquidity becomes scarce, borrowers draw funds from

\footnotetext{
${ }^{16}$ For example, passage of the Financial Modernization Act in 1999 may have increase bank stock return volatility temporarily by increasing speculation about merger activity among financial companies.

${ }^{17}$ We have also estimated our model for above and below median sized banks. For both samples we find similar results for the coefficients on the loan commitments and transactions deposit variables and their interaction, both in terms of magnitudes and levels of significance.
} 
pre-existing bank loan commitments at the same time that funding flows into bank transaction deposit accounts (Gatev, Schuermann and Strahan, 2005). Since liquidity demands become negatively correlated when spreads rise, we would expect the hedging term to become much larger then.

To test this idea, we separate the data into two regimes, one when the paper-bill spread is above 75 basis points (the $95^{\text {th }}$ percentile of its distribution) and the other when the spread is below 75 basis points (Table 7). By comparison, recall from Table 2 that the average CP spread over the sample period is about 40 basis points. During the 1998 crisis, the spread rose above 100 basis points.

The results indicate that transactions deposits do in fact act as a more powerful hedge when $\mathrm{CP}$ rates are unusually high (Table 7, columns 1 and 2). When the commercial paper spread is above 75 basis points, there is a much stronger positive link from loan commitments to risk (the linear coefficient on loan commitments rises from 0.76 to 1.0 ), and also a greater hedge associated with transactions deposit (the interaction effect nearly triples, from -1.3 to -3.2). ${ }^{18}$ The increase in magnitude in the hedging term is significant at the two percent level (column 3). We also find a significant increase in the coefficient on bank size. During normal market conditions, we find no correlation between size and volatility, whereas larger banks have higher stock-return volatility than smaller banks when CP spreads are wide.

To understand the economic impact, these coefficients suggest that increased loan commitments come with higher risk at banks with low levels of transactions deposits, but lower risk for banks with high levels of transactions deposits. For example, for banks

\footnotetext{
${ }^{18}$ We have also estimated the model during periods of high and low spreads using realized volatility as the dependent variable. In this case, the increase in the magnitude of the hedging term is somewhat larger than the increase reported in Table 7.
} 
with transactions deposit ratio of 0.38 - at the $90^{\text {th }}$ percentile of the distribution - an increase in loan commitments lowers stock-return volatility by 1.7 percentage points. This contrast is made plain in Figure 3, where we plot the relationship between stockreturn volatility and loan commitments during periods of high CP spreads, again comparing banks at the $10^{\text {th }}$ and $90^{\text {th }}$ percentiles of the transactions deposit distribution. ${ }^{19}$

Table 8 reports a similar test for the effects of varying market conditions. In these models, rather than split the sample into normal and high-spread periods, we simply add an interaction between the level of the paper-bill spread and the transactions deposit and loan commitment variables. Here, we again find that the hedging of the two liquidity variables is stronger during periods of tight markets (wide spreads). Together, the results of Tables 7 and 8 are consistent with the interpretation of our findings as related to liquidity risk by banks because the demands to provide liquidity to borrowers are greatest when market spreads widen. The greater hedging effects are consistent with our earlier finding that funding supply to banks increases during period of high spreads, thus offsetting the increase in liquidity demands from borrowers during those periods.

\section{Conclusion}

Transactions deposits reduce liquidity-risk exposure stemming from bank lending. Banks with high levels of transactions deposits do not face high risk even if they are exposed on the asset side to un-drawn loan commitments. In contrast, banks exposed to loan-liquidity risk without high levels of transactions deposits $d o$ have high risk. The

\footnotetext{
${ }^{19}$ We have also separated our transaction deposit variable into demand deposits and other transactions deposits. We find no statistically significant difference across the two - that is, both kinds of transactions accounts seem to work to help hedge asset-side liquidity risk. Thus, we only report the results here for the total ratio of transactions deposits to total deposits.
} 
deposit-lending hedge becomes especially powerful during periods of tight markets, when funds move out of the securities markets and into banks. The results are particularly striking to us because they reverse the standard notion of liquidity risk at banks, where runs from depositors had been seen as the cause of trouble (e.g. Diamond and Dybvig, 1983). Today, because safety nets protect banks, they are viewed as safe havens for funds. Investors seem to move money into deposits during periods of market turmoil. These funding inflows allowing banks to supply credit when markets can't or won't. 


\section{References}

Berger, Allen N., and Christa H.S. Bouwman, 2005, "Bank Capital and Liquidity Production,” mimeo, June 2005.

Berlin, Mitchell and Loretta J. Mester, 1999, "Deposits and Relationship Lending," Review of Financial Studies 12(3), 579-607.

Boyd, John and Mark Gertler, 1994, “Are Banks Dead? Or, Are the Reports Greatly Exaggerated?” Federal Reserve Bank of Minneapolis, Quarterly Review (Summer 1994), 1-19.

Calomiris, Charles, and Charles Kahn, 1991, "The Role of Demandable Debt in Structuring Optimal Banking Arrangements,” American Economic Review 81, 497-513.

Chava, Sudheer and Amiyatosh Purnanadam, 2005, "The Effect of Banking Crisis on Bank Dependent Borrowers,” mimeo, October 5, 2005.

Demsetz, Rebecca S. and Philip E. Strahan, 1997, “Diversification, Size, and Risk at Bank Holding Companies,” Journal of Money, Credit and Banking 29 (3), 300-313.

Diamond, Douglas and Philip Dybvig, 1983, “Bank Runs, Deposit Insurance, and Liquidity,” Journal of Political Economy 91(3), 401-419.

Diamond, Douglas and Raghuram Rajan, 2001, "Liquidity Risk, Liquidity Creation and Financial Fragility: A Theory of Banking,” Journal of Political Economy 91, 401-419.

Edwards, Franklin, 1999, "Hedge Funds and the Collapse of Long-Term Capital Management,” Journal of Economic Perspectives 13(2), 189-209.

Fama, Eugene, 1985, “What's Different about Banks?” Journal of Monetary Economics 15:1, 29-39.

Flannery, Mark, 1994, "Debt Maturity and the Deadweight Costs of Leverage: Optimally Financing Banking Firms, American Economic Review 84, 320-331.

Furfine, Craig, 2002, “The Costs and Benefits of Moral Suasion: Evidence from the Rescue of Long-Term Capital Management,” Federal Reserve Bank of Chicago, Working Paper no. 2002-11.

Garber, Peter, and David Weisbrod, 1990, “Banks in the Market for Liquidity,” working paper no. 3381, National Bureau of Economic Research. 
Gatev, Evan and Philip E. Strahan, 2006, "Banks Advantage in Hedging Liquidity Risk: Theory and Evidence from the Commercial Paper Market,” Journal of Finance 61:2, 867-892.

Gatev, Evan, Til Schuermann, and Philip E. Strahan, 2005, “How Do Banks Manage Liquidity Risk? Evidence from the Equity and Deposit Markets in the Fall of 1998”, forthcoming in Mark Carey and René Stulz (eds.), Risks of Financial Institutions, Chicago, IL: University of Chicago Press.

Kane, Edward, 1974, “All for the Best: The Federal Reserve Board's 60 ${ }^{\text {th }}$ Annual Report,” American Economic Review 64, December, 835-850.

Kashyap, Anil K, Raghuram G. Rajan and Jeremy C. Stein, 2002, "Banks as Liquidity Providers: An Explanation for the Co-existence of Lending and Deposit-Taking,” Journal of Finance 57(1), 33-74.

Khwaja, Asim Isaz and Atif Mian, 2005, “Tracing the Impact of Bank Liquidity Shocks,” mimeo, June 2005.

Kroszner, Randall and Philip E. Strahan, 2005, "Bank Regulations in the United States: Causes, Consequences and Implications for the Future,” mimeo.

Kho, Bong-Chan, Dong Lee and René M. Stulz, 2000, “US Banks, Crises and Bailouts: From Mexico to LTCM,” American Economic Review 90(2), 28-31.

Loutskina, Elena, 2005, "Does Securitization affect Bank Lending? Evidence from Bank Responses to Funding Shocks,” mimeo, March 2005.

Loutskina, Elena, and Philip E. Strahan, 2006, “Securitization and the Declining Impact of Bank Financial Condition on Loan Supply: Evidence from Mortgage Acceptance Rates,” mimeo, January 2006.

Mester, Loretta, Nakamura, Leonard and Micheline Renault, 2003, "Checking Accounts and Bank Monitoring,” Federal Reserve Bank of Philadelphia working paper no. 01-3/R.

Mishkin, Frederic and Philip E. Strahan, "What will Technology do to Financial Structure?” 1998, in The Effect of Technology on the Financial Sector, BrookingsWharton Papers on Financial Services, edited by Robert Litan and Anthony Santomero, 249-87.

Myers, Stewart C. and Raghuram G. Rajan, 1998, “The Paradox of Liquidity,” Quarterly Journal of Economics 113, 733-71.

O’Hara, Maureen and Wayne Shaw, 1990, "Deposit Insurance and Wealth Effects: The Benefit of Being Too Big to Fail,” Journal of Finance 45(4), 1587-1600. 
Paravisini, Daniel, 2004, "Constrained Banks, Constrained Borrowers: The Effects of Bank Liquidity on the Availability of Credit,” MIT mimeo, November.

Pennacchi, George. 2006, “Deposit Insurance, Bank Regulation and Financial System Risk,” Journal of Monetary Economics 53, 1-30.

Saidenberg, Marc R. and Philip E. Strahan, 1999, “Are Banks Still Important for Financing Large Businesses?” 1999, Federal Reserve Bank of New York’s Current Issues in Economics and Finance 5(12), 1-6.

Stiroh, Kevin, 2005, "New Evidence on the Determinants of Bank Specific Risk," mimeo, Federal Reserve Bank of New York.

Strahan, Philip E., 2005, “Banking Structure and Lending: What We Do and Do Not Know,” mimeo, January 2005. 
Table 1: Mean Bank Characteristics, By Transactions Deposits and Unused Commitments

\begin{tabular}{|c|c|c|c|}
\hline & \multicolumn{3}{|c|}{ Transactions Deposits / Total Deposits (TD): } \\
\hline & TD < 33rd Percentile & 33rd Pct. $>=$ TD $<67$ th Pct. & 67th Pct. $<=$ TD \\
\hline & $(1)$ & $(2)$ & (3) \\
\hline \multicolumn{4}{|l|}{ Unused Commitments / (Commitments + Loans) (LC) } \\
\hline Stock-return Volatility & 0.28 & 0.29 & 0.32 \\
\hline$($ Cash + Securities $) /$ Assets & 0.32 & 0.31 & 0.33 \\
\hline Fed Funds Purchased / Assets & 0.07 & 0.08 & 0.07 \\
\hline Equity / Assets & 0.08 & 0.08 & 0.11 \\
\hline \multicolumn{4}{|l|}{ 33rd Percentile $<=$ LC $<67$ th Percentile } \\
\hline Stock-return Volatility & 0.29 & 0.29 & 0.30 \\
\hline$($ Cash + Securities $) /$ Assets & 0.32 & 0.31 & 0.33 \\
\hline Assets (Billions of \$s) & 17.85 & 21.64 & 16.53 \\
\hline Fed Funds Purchased / Assets & 0.09 & 0.10 & 0.11 \\
\hline Equity / Assets & 0.08 & 0.08 & 0.07 \\
\hline \multicolumn{4}{|l|}{ 67th Percentile <= LC } \\
\hline Stock-return Volatility & 0.36 & 0.32 & 0.31 \\
\hline (Cash + Securities) / Assets & 0.34 & 0.30 & 0.33 \\
\hline Assets (Billions of \$s) & 34.63 & 89.10 & 83.36 \\
\hline Fed Funds Purchased / Assets & 0.07 & 0.10 & 0.10 \\
\hline Equity / Assets & 0.08 & 0.08 & 0.08 \\
\hline Mean Commitments Ratio & 0.30 & 0.31 & 0.37 \\
\hline
\end{tabular}


Table 2: Summary Statistics for Variables Included in Regression Models

\begin{tabular}{|c|c|c|}
\hline & Mean & $\begin{array}{c}\text { Standard } \\
\text { Deviation } \\
\end{array}$ \\
\hline Dependent Variable & $(1)$ & $(2)$ \\
\hline $\begin{array}{r}\text { Stock-return Volatility } \\
\text { (Annualized Return Standard Deviation) }\end{array}$ & 0.30 & 0.13 \\
\hline \multicolumn{3}{|l|}{ Commitments and Deposits } \\
\hline Commitments / (Commitments + Loans) & 0.32 & 0.15 \\
\hline $\begin{array}{r}\text { (Commitments-Retail Commitments) / } \\
\text { (Commitments-Retail Commitments) + Loans)) }\end{array}$ & 0.24 & 0.13 \\
\hline Transactions Deposits / Total Deposits & 0.26 & 0.11 \\
\hline \multicolumn{3}{|l|}{ Controls for Market Conditions } \\
\hline $\begin{array}{r}\text { Volatility of S\&P } 500 \\
\text { (Annualized Return Standard Deviation) }\end{array}$ & 0.16 & 0.06 \\
\hline Commercial Paper - T-Bill Yield Spread (\% pts) & 0.40 & 0.21 \\
\hline Yield on Three-Month Treasury Bill (\% pts) & 4.52 & 1.55 \\
\hline \multicolumn{3}{|l|}{ Controls for Bank Characteristics } \\
\hline Assets (Billions of \$s) & 34.47 & 69.89 \\
\hline (Cash + Securities) / Assets & 0.32 & 0.12 \\
\hline Fed Funds Purchased / Assets & 0.09 & 0.06 \\
\hline Equity / Assets & 0.08 & 0.04 \\
\hline
\end{tabular}


Table 3: Regressions of Bank Stock Return Volatility on Liquidity Exposure and Transaction Deposits Ratio

Unused Commitments and Deposits

Commitments / (Commitments + Loans)

(Commitments-Retail Commitments) /

(Commitments-Retail Commitments) + Loans))

Transactions Deposits / Total Deposits

Commitments / (Commitments + Loans) *

Transactions Deposits / Total Deposits

(Commitments-RC) / (Commitments-RC+Loans) *

Transactions Deposits / Total Deposits

Controls for Market Conditions

Log of Volatility of S\&P 500

Paper-Bill Spread

Yield on Three-Month Treasury Bill

Controls for Bank Characteristics

Log of Assets

$($ Cash + Securities) / Assets

Fed Funds Purchased / Assets

Equity / Assets

Observations

Number of Independent Clusters (banks)

R-squared
Dependent Variable:

Log of Weekly Bank Stock-Return Volatility

Predicted Volatility from GARCH $(1,1)$

$\begin{array}{cccc}(1) & (2) & (3) & (4) \\ 0.788 & 0.82 & - & - \\ (7.19)^{* *} & (6.94)^{* *} & - & - \\ - & - & 0.951 & 1.005 \\ - & - & (3.55)^{* *} & (3.63)^{* *} \\ 0.701 & 0.772 & 0.485 & 0.497 \\ (4.66)^{* *} & (3.37)^{* *} & (1.90) & (1.80) \\ -1.604 & -1.749 & - & - \\ (4.46)^{* *} & (3.52)^{* *} & - & - \\ - & - & -1.702 & -1.709 \\ - & - & (2.19)^{*} & (2.07)^{*} \\ & & & \\ 0.494 & 0.499 & 0.464 & 0.46 \\ (21.43)^{* *} & (20.82)^{* *} & (16.80)^{* *} & (16.43)^{* *} \\ 0.085 & 0.084 & 0.103 & 0.103 \\ (3.79)^{* *} & (3.80)^{* *} & (4.53)^{* *} & (4.51)^{* *} \\ 0.031 & 0.03 & 0.031 & 0.03 \\ (6.96)^{* *} & (6.44)^{* *} & (6.76)^{* *} & (6.44)^{* *}\end{array}$

$\begin{array}{llll}-0.001 & -0.003 & -0.008 & -0.012\end{array}$

$\begin{array}{llll}(0.06) & (0.23) \quad(0.57) \quad(0.85)\end{array}$

$\begin{array}{llll}- & -0.03 & - & -0.108\end{array}$

$\begin{array}{llll}- & (0.25) & - & (0.83)\end{array}$

$\begin{array}{llll}- & 0.067 & - & -0.098\end{array}$

$\begin{array}{llll}- & (0.26) & - & (0.37)\end{array}$

$\begin{array}{llll}- & -0.174 & - & 0.095\end{array}$

\begin{tabular}{cccc}
- & $(0.41)$ & - & $(0.22)$ \\
\hline 49,527 & 49,527 & 49,527 & 49,527 \\
170 & 170 & 170 & 170
\end{tabular}

$28.77 \% \quad 28.80 \% \quad 27.86 \% \quad 28.02 \%$

Robust standard errors in parentheses, clustered by bank. All regressions include an intercept.

* significant at $5 \%$;* significant at $1 \%$ 
Table 4: Regressions of Bank Stock Return Volatility on Liquidity Exposure and Transaction Deposits Ratio

\begin{tabular}{|c|c|c|c|c|}
\hline & & & & \\
\hline Unused Commitments and Deposits & $(1)$ & $(2)$ & (3) & (4) \\
\hline Commitments / (Commitments + Loans) & 0.803 & 0.859 & - & - \\
\hline & $(7.77)^{* *}$ & $(7.05)^{* *}$ & - & - \\
\hline (Commitments-Retail Commitments) / & - & - & 0.904 & 0.991 \\
\hline (Commitments-Retail Commitments) + Loans)) & - & - & $(3.33)^{* *}$ & $(3.31)^{* *}$ \\
\hline Transactions Deposits / Total Deposits & 0.754 & 0.899 & 0.545 & 0.621 \\
\hline & $(6.04)^{* *}$ & $(3.53)^{* *}$ & $(2.37)^{*}$ & $(2.03)^{*}$ \\
\hline Commitments / (Commitments + Loans) $*$ & -1.541 & -1.811 & - & - \\
\hline Transactions Deposits / Total Deposits & $(5.00)^{* *}$ & $(3.36)^{* *}$ & - & - \\
\hline (Commitments-RC) / (Commitments-RC+Loans) * & - & - & -1.633 & -1.782 \\
\hline Transactions Deposits / Total Deposits & - & - & $(2.20)^{*}$ & $(1.98)^{*}$ \\
\hline Controls for Market Conditions & & & & \\
\hline Log of Volatility of S\&P 500 & 0.511 & 0.522 & 0.481 & 0.483 \\
\hline & $(22.01)^{* *}$ & $(20.62)^{* *}$ & $(17.35)^{* *}$ & $(15.84)^{* *}$ \\
\hline Paper-Bill Spread & 0.234 & 0.231 & 0.253 & 0.25 \\
\hline & $(8.59)^{* *}$ & $(8.54)^{* *}$ & $(9.50)^{* *}$ & $(9.38)^{* *}$ \\
\hline Yield on Three-Month Treasury Bill & 0.014 & 0.013 & 0.014 & 0.013 \\
\hline & $(3.17)^{* *}$ & $(2.61)^{* *}$ & $(2.98)^{* *}$ & $(2.64)^{* *}$ \\
\hline Controls for Bank Characteristics & & & & \\
\hline Log of Assets & 0.001 & -0.003 & -0.005 & -0.009 \\
\hline & $(0.03)$ & $(0.24)$ & $(0.32)$ & $(0.60)$ \\
\hline (Cash + Securities) / Assets & - & -0.039 & - & -0.1 \\
\hline & - & $(0.30)$ & - & $(0.70)$ \\
\hline Fed Funds Purchased / Assets & - & -0.016 & - & -0.187 \\
\hline & - & $(0.06)$ & - & $(0.66)$ \\
\hline Equity / Assets & - & -0.379 & - & -0.113 \\
\hline & - & $(0.78)$ & - & $(0.23)$ \\
\hline Observations & 49,527 & 49,527 & 49,527 & 49,527 \\
\hline Number of Independent Clusters (banks) & 170 & 170 & 170 & 170 \\
\hline R-squared & $12.37 \%$ & $12.41 \%$ & $11.80 \%$ & $11.87 \%$ \\
\hline
\end{tabular}

Robust standard errors in parentheses, clustered by bank. All regressions include an intercept.

* significant at $5 \%$; ** significant at $1 \%$ 
Table 5: Regressions of Bank Stock Return Volatility on Liquidity Exposure and Transaction Deposits Ratio - Between vs. Within Estimator

Unused Commitments and Deposits

Commitments / (Commitments + Loans)

Transactions Deposits / Total Deposits

Commitments / (Commitments + Loans) *

Transactions Deposits / Total Deposits

Controls for Market Conditions

Log of Volatility of S\&P 500

Paper-Bill Spread

Yield on Three-Month Treasury Bill

Controls for Bank Characteristics

Log of Assets

(Cash + Securities) / Assets

Fed Funds Purchased / Assets

Equity / Assets

Observations

Number of Independent Clusters (banks)

R-squared
Dependent Variable:

Log of Weekly Bank Stock-Return Volatility

Between Estimator

(1)

0.762

$(4.58)^{* *}$

0.815

$(3.55)^{* *}$

$-1.384$

(2.00)*

(2)

0.805

$(3.94)^{* *}$

1.013

$(2.98)^{* *}$

$-1.739$

(2.08)*

Within Estimator

$\begin{array}{cccc}0.549 & 0.569 & 0.447 & 0.452 \\ (6.52)^{* *} & (6.47)^{* *} & (24.61)^{* *} & (25.01)^{* *} \\ -1.84 & -1.783 & 0.163 & 0.162 \\ (4.48)^{* *} & (4.22)^{* *} & (8.63)^{* *} & (8.60)^{* *} \\ 0.204 & 0.195 & 0.024 & 0.024 \\ (5.39)^{* *} & (4.85)^{* *} & (5.11)^{* *} & (5.15)^{* *}\end{array}$

$$
-0.014
$$

(0.83)

$-0.014$

(0.72)

0.057

-

$-$

$-$

$-$

-

-

49,527

170

(0.38)

$-0.013$

(0.04)

$-0.527$

(0.84)

$39.81 \%$
49,527

170

40.15\%
$-0.014$

(0.59)

-

-

$-$

$-$

$-$

-

49,527

170

$29.73 \%$
0.011

(0.41)

0.225

(1.59)

$-0.458$

(1.93)

$-1.125$

(2.22)*

49,527

170

$30.28 \%$

Robust standard errors in parentheses, clustered by bank. All regressions include an intercept and bank effects.

* significant at $5 \%$; ** significant at $1 \%$ 
Table 6: Regressions of Bank Stock Return Volatility on Liquidity Exposure and Transaction Deposits Ratio - Add Controls for Credit Risk, Market Risk \& Time Dummies

Dependent Variable:

Unused Commitments and Deposits

Commitments / (Commitments + Loans)

Transactions Deposits / Total Deposits

Commitments / (Commitments + Loans) *

Transactions Deposits / Total Deposits

Controls for Market Conditions

Log of Volatility of S\&P 500

Paper-Bill Spread

Yield on Three-Month Treasury Bill

Controls for Bank Characteristics

Log of Assets

$($ Cash + Securities $) /$ Assets

Fed Funds Purchased / Assets

Equity / Assets

Controls for Credit \& Market Risks

C\&I Loans / Assets

Commercial Real Estate Loans / Assets

Non-Performing Loans / Assets

Trading Assets / Assets

Loan Loss Provisions / Assets

Net Charge-offs / Assets

Includes Weekly Indicators?

Observations

Number of Independent Clusters (banks)

R-squared
Log of Weekly Bank Stock-Return Volatility

\begin{tabular}{cccc}
\hline$(1)$ & $(2)$ & $(3)$ & $(4)$ \\
0.671 & 0.569 & 0.665 & 0.563 \\
$(5.81)^{* *}$ & $(4.93)^{* *}$ & $(6.11)^{* *}$ & $(5.11)^{* *}$ \\
0.372 & 0.346 & 0.539 & 0.53 \\
$(2.09)^{*}$ & $(2.09)^{*}$ & $(3.12)^{* *}$ & $(3.25)^{* *}$ \\
-1.41 & -1.235 & -1.36 & -1.23 \\
$(3.39)^{* *}$ & $(3.25)^{* *}$ & $(3.43)^{* *}$ & $(3.31)^{* *}$
\end{tabular}

$\begin{array}{cc}0.512 & 0.504 \\ (23.07)^{* *} & (22.37)^{* *} \\ 0.103 & 0.114 \\ (4.48)^{* *} & (4.88)^{* *} \\ 0.027 & 0.026 \\ (5.39)^{* *} & (5.29)^{* *}\end{array}$

$-0.017$

$-0.012$

$-0.021$

$-0.017$

(1.48)

(1.15)

(1.81)

(1.63)

0.287

0.373

0.159

0.252

(2.15)*

$(2.82)^{* *}$

(1.33)

(2.11)*

0.138

0.141

0.165

0.168

(0.56)

(0.58)

(0.71)

(0.73)

0.475

0.578

0.386

(2.48)*

(1.49)

0.431

(1.66)

Robust standard errors in parentheses, clustered by bank. All regressions include an intercept.

* significant at 5\%; ** significant at $1 \%$

\begin{tabular}{cccc}
0.366 & 0.415 & 0.254 & 0.31 \\
$(2.07)^{*}$ & $(2.38)^{*}$ & $(1.35)$ & $(1.68)$ \\
-0.154 & 0.008 & -0.306 & -0.166 \\
$(0.60)$ & $(0.03)$ & $(1.14)$ & $(0.64)$ \\
11.512 & 8.561 & 9.959 & 7.45 \\
$(5.82)^{* *}$ & $(4.50)^{* *}$ & $(4.51)^{* *}$ & $(3.75)^{* *}$ \\
0.388 & 0.498 & 0.315 & 0.417 \\
$(1.93)$ & $(2.62)^{* *}$ & $(1.75)$ & $(2.42)^{*}$ \\
- & 22.46 & - & 20.164 \\
- & $(4.88)^{* *}$ & - & $(4.65)^{* *}$ \\
- & 14.73 & - & 16.688 \\
- & $(1.94)$ & - & $(2.32)^{*}$ \\
\hline No & No & Yes & Yes \\
49,527 & 49,527 & 49,527 & 49,527 \\
170 & 170 & 170 & 170 \\
$36.59 \%$ & $37.62 \%$ & $49.53 \%$ & $50.41 \%$ \\
\hline
\end{tabular}


Table 7: Regressions of Bank Stock Return Volatility on Liquidity Exposure and Transaction Deposits Ratio - Hi and Low Paper-Bill Spread Regimes

\begin{tabular}{|c|c|c|c|}
\hline \multirow[b]{3}{*}{ Unused Commitments and Deposits } & \multicolumn{3}{|c|}{$\begin{array}{l}\text { Dependent Variable: } \\
\text { Log of Weekly Bank Stock Return Volatility } \\
\text { P-Value }\end{array}$} \\
\hline & $<75$ Bps & $>=75$ Bps & $H_{0}:(1)=(2)$ \\
\hline & $(1)$ & $(2)$ & (3) \\
\hline Commitments / (Commitments + Loans) & $\begin{array}{c}0.761 \\
(8.12)^{* *}\end{array}$ & $\begin{array}{c}1.002 \\
(4.67)^{* *}\end{array}$ & 0.212 \\
\hline Transactions Deposits / Total Deposits & $\begin{array}{c}0.632 \\
(3.35)^{* *}\end{array}$ & $\begin{array}{c}1.396 \\
(3.11)^{* *}\end{array}$ & 0.057 \\
\hline $\begin{array}{l}\text { Commitments / (Commitments + Loans) } \\
\text { Transactions Deposits / Total Deposits }\end{array}$ & $\begin{array}{c}-1.317 \\
(3.42)^{* *}\end{array}$ & $\begin{array}{l}-3.196 \\
(3.47)^{* *}\end{array}$ & 0.02 \\
\hline \multicolumn{4}{|l|}{ Controls for Bank Characteristics } \\
\hline Log of Assets & $\begin{array}{l}-0.006 \\
(0.56)\end{array}$ & $\begin{array}{c}0.042 \\
(2.53)^{*}\end{array}$ & 0.001 \\
\hline (Cash + Securities) / Assets & $\begin{array}{l}-0.063 \\
(0.60)\end{array}$ & $\begin{array}{l}-0.304 \\
(1.74)\end{array}$ & 0.12 \\
\hline Fed Funds Purchased / Assets & $\begin{array}{l}0.129 \\
(0.52)\end{array}$ & $\begin{array}{l}0.316 \\
(0.88)\end{array}$ & 0.617 \\
\hline Equity / Assets & $\begin{array}{l}0.411 \\
(1.38)\end{array}$ & $\begin{array}{l}-0.765 \\
(1.18)\end{array}$ & 0.043 \\
\hline P-Value for F-Test that all coefficients are equal & - & - & 0.001 \\
\hline Includes Weekly Indicators? & Yes & Yes & - \\
\hline Observations & 46,856 & 2,671 & - \\
\hline Number of Independent Clusters (banks) & 170 & 154 & - \\
\hline R-squared & $43.53 \%$ & $39.39 \%$ & - \\
\hline
\end{tabular}

Robust standard errors in parentheses, clustered by bank. All regressions include an intercept.

* significant at $5 \%$; ** significant at $1 \%$ 
Table 8: Regressions of Bank Stock Return Volatility on Liquidity Exposure and Transaction Deposits Ratio - With Paper-Bill Spread Interaction Terms

\begin{tabular}{|c|c|c|}
\hline \multirow[b]{2}{*}{ Unused Commitments and Deposits } & \multicolumn{2}{|c|}{ Dependent Variable: } \\
\hline & $(1)$ & $(2)$ \\
\hline \multirow[t]{2}{*}{ Commitments / (Commitments + Loans) } & 0.709 & 0.609 \\
\hline & $(4.05)^{* *}$ & $(3.91)^{* *}$ \\
\hline \multirow[t]{2}{*}{ Transactions Deposits / Total Deposits } & 0.575 & 0.337 \\
\hline & $(2.79)^{* *}$ & $(2.15)^{*}$ \\
\hline Commitments / (Commitments + Loans) * & -0.901 & -0.477 \\
\hline Transactions Deposits / Total Deposits & $(1.80)$ & $(1.07)$ \\
\hline \multicolumn{3}{|l|}{ Interaction Between Paper-Bill Spread and: } \\
\hline \multirow[t]{2}{*}{ Commitments / (Commitments + Loans) } & 0.274 & 0.554 \\
\hline & $(0.82)$ & $(1.64)$ \\
\hline \multirow[t]{2}{*}{ Transactions Deposits / Total Deposits } & 0.624 & 1.204 \\
\hline & $(2.07)^{*}$ & $(2.45)^{*}$ \\
\hline Commitments / (Commitments + Loans) * & -2.044 & -3.042 \\
\hline Transactions Deposits / Total Deposits & $(2.49)^{*}$ & $(2.71)^{* *}$ \\
\hline Controls for Bank Characteristics ${ }^{1}$ & \multicolumn{2}{|c|}{ Included, coefficients not reported } \\
\hline Includes Weekly Indicators? & Yes & Yes \\
\hline Observations & 49,527 & 49,527 \\
\hline Number of Independent Clusters (banks) & 170 & 170 \\
\hline R-squared & $45.59 \%$ & $45.87 \%$ \\
\hline
\end{tabular}

Dependent Variable: 
Figure 1 Panel A

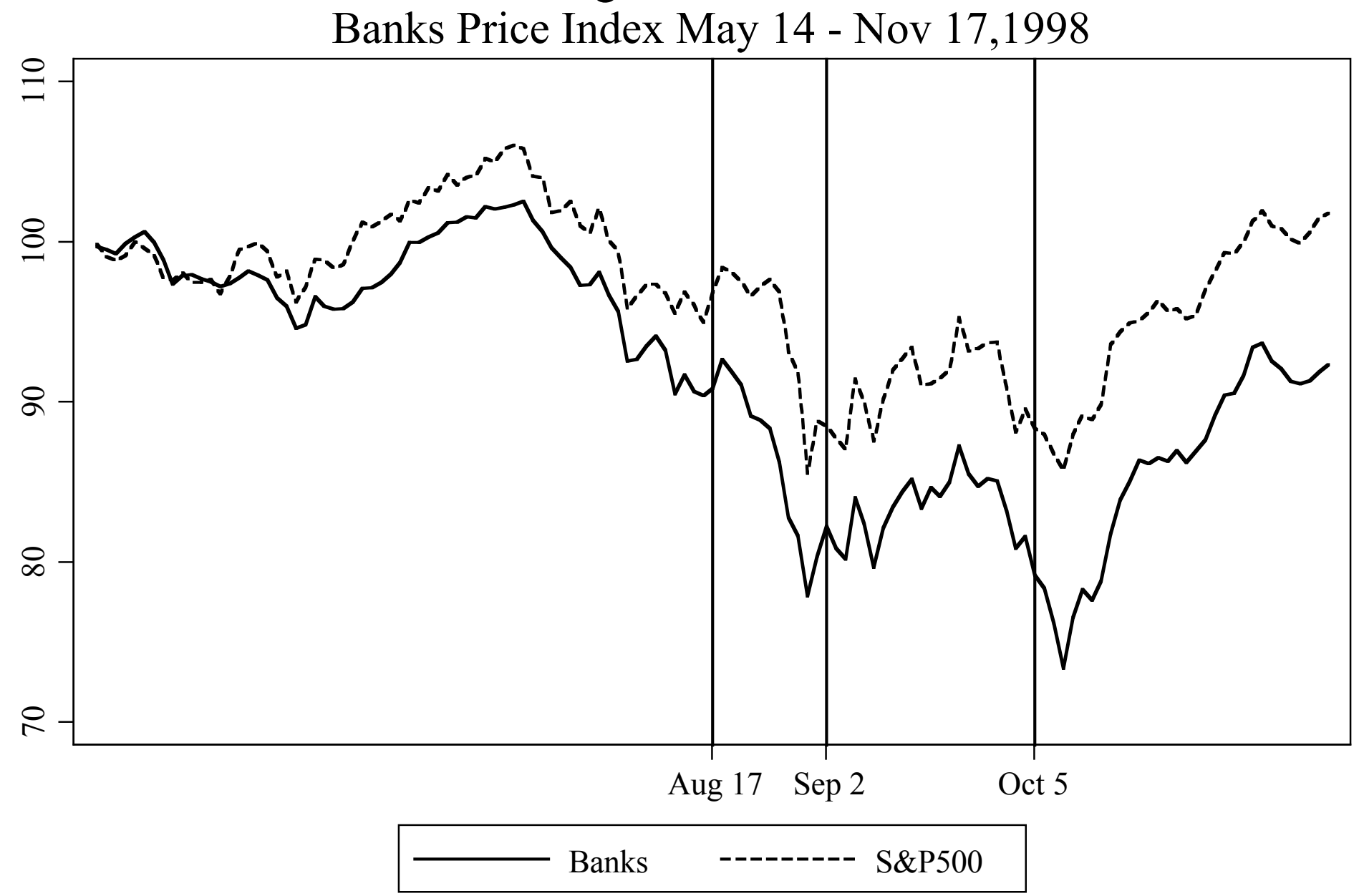


Figure 1 Panel B

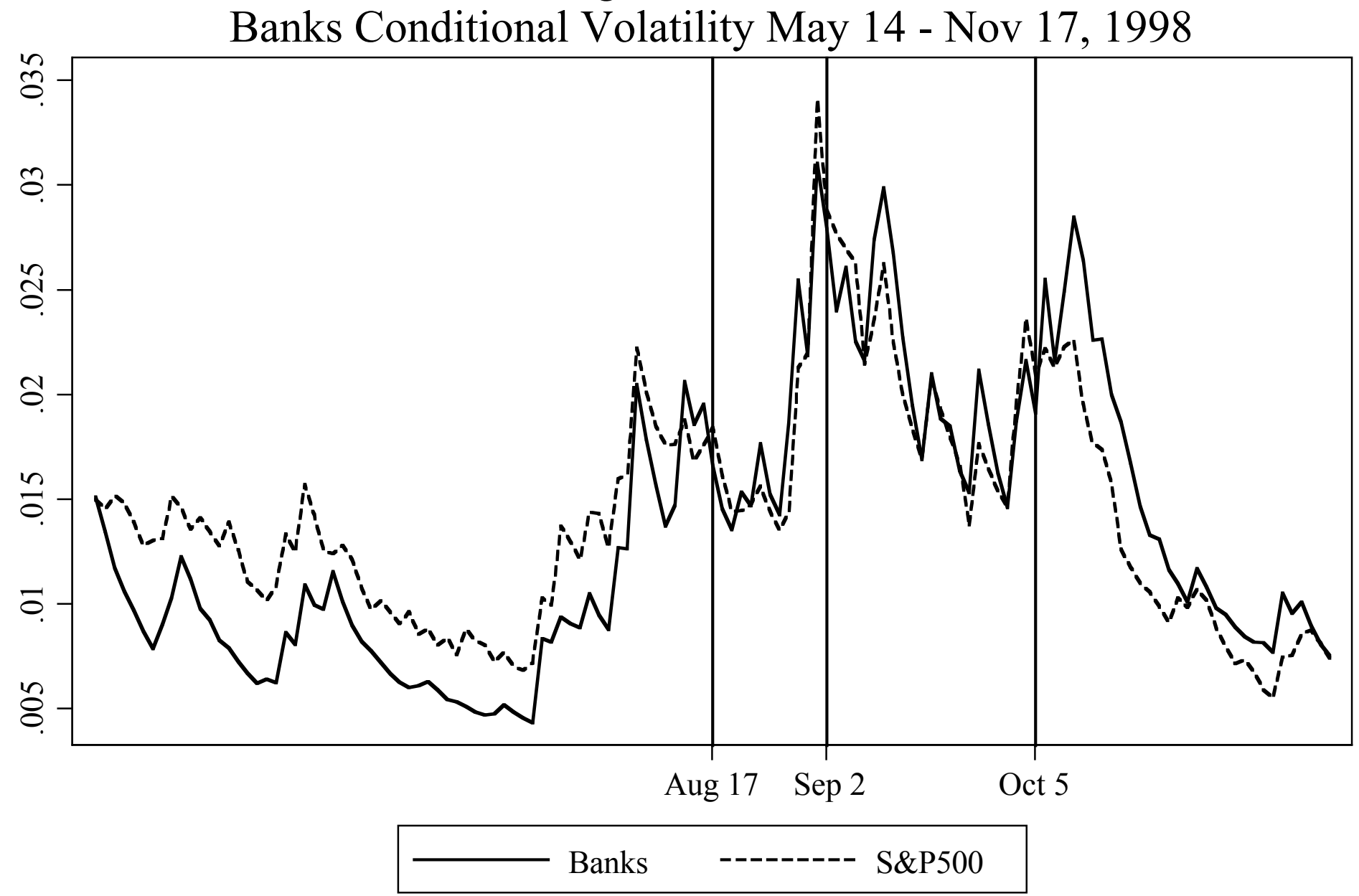




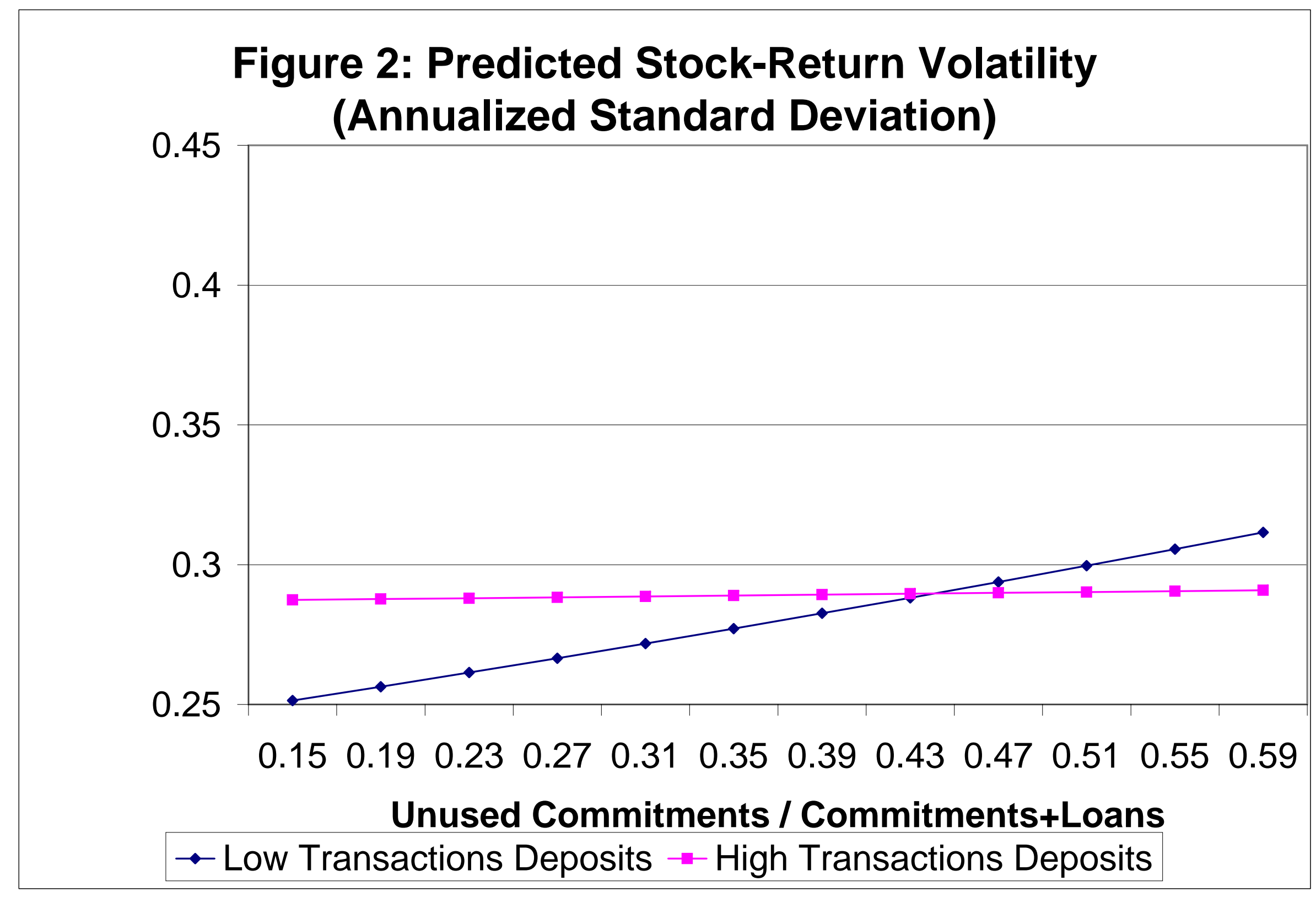




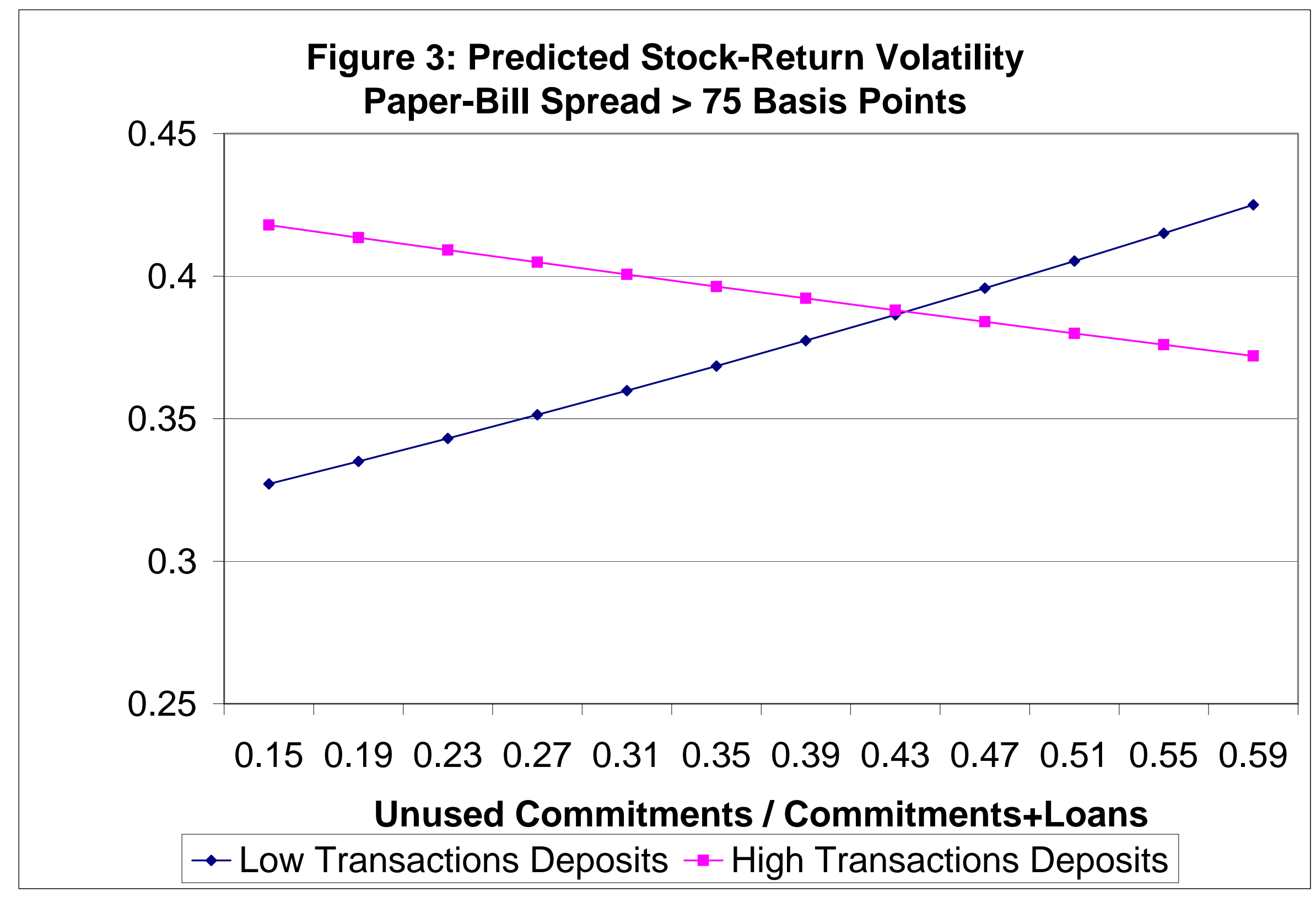

